\title{
GREEN SUPPLY CHAIN MANAGEMENT IN CROATIAN COMPANIES
}

\author{
Tihomir OPETUK, Goran DUKIC, Hrvoje CAJNER, Davor KOLAR
}

\begin{abstract}
The scope of this paper is to present current state and trends of Green Supply Chain Management (GSCM) in Croatian companies. Due to the need for reduction of GHG emissions related to the climate change, many standards, directives, concepts, methods and models dealing with sustainability have appeared. The first part of the paper consists of an overview of GSCM where the greening diagram of GSCM is presented. The second part of the paper presents the survey which has been carried out in the Croatian business sector in view of current state and trends, barriers and drivers of the GSCM implementation. According to the results of the survey, barriers and drivers of the GSCM implementation are ranked by its significance and are compared with similar surveys carried out in the European Union (EU) and the United States of America (USA). New categorization of the drivers of the GSCM implementation is presented using the factor analysis.
\end{abstract}

Keywords: barriers; drivers; Green Supply Chain Management; survey

\section{INTRODUCTION}

Nowadays, the increase in greenhouse gas (GHG) emissions in the atmosphere is currently one of the most serious environmental threats. Due to GHG emissions we will be witnesses of climate change which will cause damaging impacts in the next few decades [1]. These will primarily affect the natural and human systems [2]. At the same time these emissions are also a limiting factor for the economic growth of some countries, especially those in the transition process [3]. One of the reasons for that is the protocol, adopted in 2012 at the Doha 2012 United Nation (UN) Climate Change Conference COP18 CMP8, at which the industrial world agreed to reduce the emissions of greenhouse gases approximately $18 \%$ below 1990 levels by 2013-2020 [4]. In the meantime, also due to the climate change and the increase in environmental awareness all over the world, the concept of Green Supply Chain Management appeared. It is often defined as integrating environmental thinking into supply chain management [5]. Within that concept, many greening elements aimed at the reduction of materials, energy, waste, pollution and emissions, or promoting the usage of recyclable materials and renewable energy sources, have been introduced in various segments of supply chains. The proof lies in a number of examples from industry, as well as in significant interest of academic community that could be seen through research papers, doctoral theses and research projects.

There are three main reasons why companies implement the greening process into their corporation $[6,7,8]$ :

- Legislation - they have to comply with the environmental regulations,

- Marketing - addressing the environmental concerns of their customers,

- Ecological awareness - mitigate the environmental impact of their production activities.

Today there are many concepts, methods and models which are dealing with ecology, cleaner production, greener supply chains, etc. However, the above-mentioned examples and literature are not always fully clear and identical in terms of terminology used, while those various concepts, methods and models are appearing as a topic with practically the same goal - greener processes of supply chain/production.

The first part of this paper is an overview of Green Supply Chain Management (GSCM). In addition, Life Cycle Assessment (LCA), Product Lifecycle Management (PLM), Product Life Cycle Management (PLCM) and Life Cycle Management (LCM), Green Logistics (GL), Sustainable Logistics (SL), Environmental Logistics (EL), Clean Logistics (CL) and Green Production (GP), Sustainable Production (SP), Environmental Production (EP), Clean Production (CP) are connected to sustainability and are therefore included in the research.

The research was based on the literature survey within two databases (SCOPUS and Science Direct) that contain relevant scientific journals, databases of doctoral theses, and standards and directives related to sustainable development. In addition to the above-mentioned concepts, methods and models, some standards and directives are also connected with sustainable development. Concepts of sustainable development are often associated with the following standards and directives:

- ISO 9001 Quality management systems - Requirements,

- ISO 14001 Environmental management systems Requirements with guidance for use,

- ISO 14040 Environmental management - Life cycle assessment - Principles and framework,

- ISO 14051 Environmental management - Material flow cost accounting - General framework,

- ISO 14062 Environmental management - Integrating environmental aspects into product design and development,

- ISO 14064 Greenhouse gases - part 1, 2, 3,

- ISO 26000 Guidance on social responsibility,

- ISO 50001 Energy management systems - Requirements with guidance for use,

- OHSAS 18001 Occupational health and safety management systems, 
- WEEE Waste Electrical and Electronic Equipment Directive,

- RoHS Directive on the restriction of the use of certain Hazardous substances in electrical and electronic equipment,

- IPP Integrated Product Policy,

- EuP Energy using Products Directive,

- ELV End of Life Vehicles Directive,

- EPA Environmental Protection Act,

- PPW Packaging and Packaging Waste Directive,

- EMAS Eco-Management and Audit Scheme Directive,

- VOC Volatile Organic Compounds Directive,

- ED Eco-design Directive.

The first part of the research relates to identifying interrelations among those concepts, methods and models' similarities and differences appearing in approaches of various authors, leading to an overall better understanding of the broad concept of GSCM.

The second part of the paper presents the survey which has been carried out in the Croatian business sector in view of current state and trends, barriers and drivers of GSCM.

\section{GREEN SUPPLY CHAIN MANAGEMENT}

From the definition of Supply Chain Management given by the Council of Supply Chain Management Professionals (CSCMP) [9], "Supply chain management encompasses the planning and management of all activities involved in sourcing and procurement, conversion, and all logistics management activities". Moreover, it includes coordination and collaboration with channel partners, i.e. suppliers, intermediaries, third party service providers and customers. In essence, supply chain management integrates supply and demand management within and across companies. Making it green, it could be simply illustrated as in Fig. 1 [7].

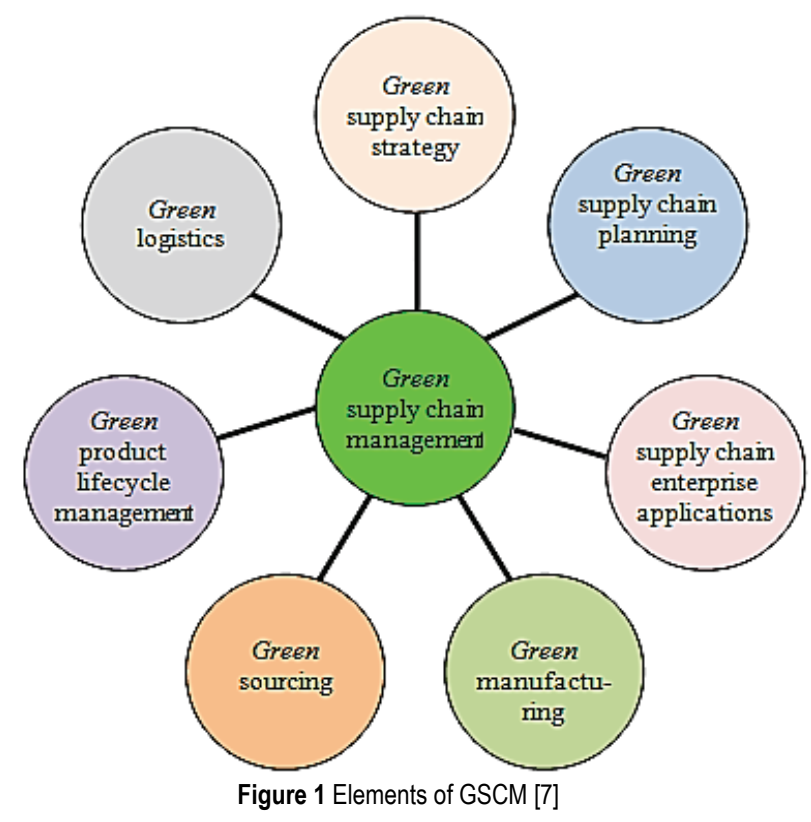

GSCM is a field of implementation of green thinking in all the segments of companies' activities and with focusing on the definition of SCM and three basic groups of activities - procurement, operations and logistics.

Additionally, there are many definitions of GSCM. Thus, other authors define GSCM as shown in Fig. 2 [10], Fig. 3 [11] and Fig. 4 [12]. According to the authors of this paper, green supply chain management could be illustrated as shown in Fig. 5.

As it can be seen from the Figs. 1 - 5, none of the authors are considering GSCM as suggested in this paper. This is also a new look at the GSCM concept. Also, this approach of defining the GSCM concept simplifies implementation of some GSCM models because it follows the most common classification of departments within a company.

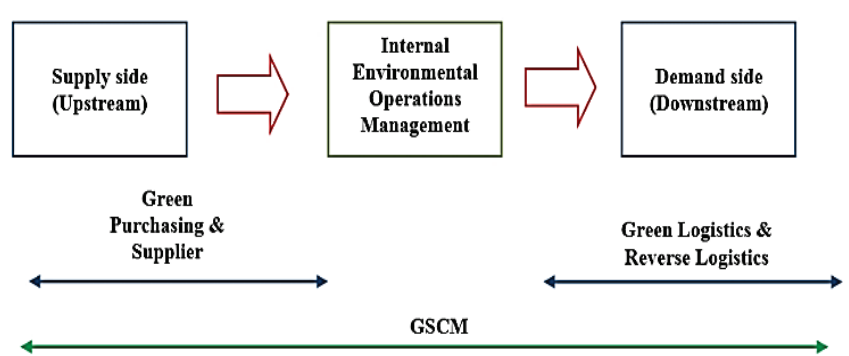

Figure 2 The GSCM concept according to Holt [10]

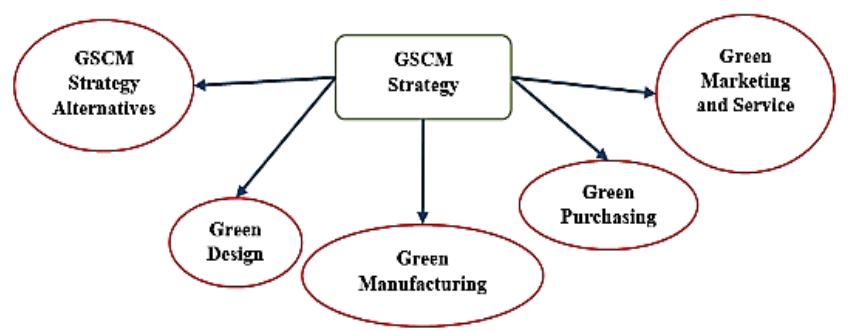

Figure 3 GSCM concept according to Chen and others [11]

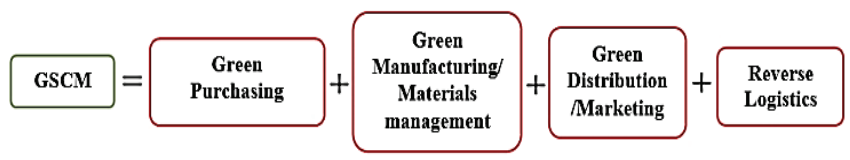

Figure 4 The GSCM concept according to Kuo-Chung and others [11]

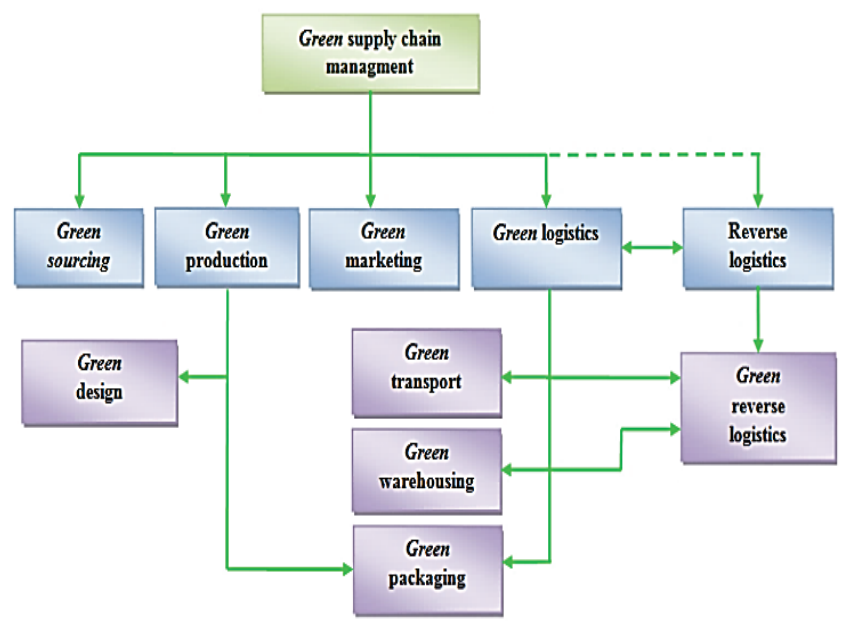

Figure 5 Greening diagram 


\section{DESIGN OF THE SURVEY}

The GSCM topic is relatively new in Croatia and the state and trends are not precisely known, which justifies the need for such a survey. The survey was carried out in the Croatian business sector. The structure of the survey is shown in Fig. 6.

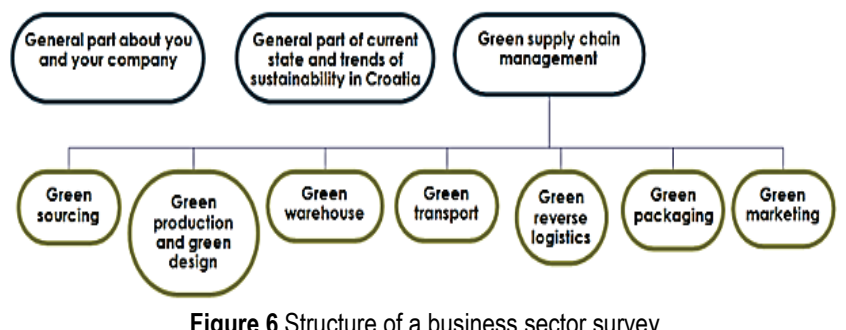

The first part of the survey includes general questions about the examinee and the company. The second part of the survey is designed to give an insight in how well they are informed about sustainable concepts, methods, models, standards and directives and whether some of them are implemented or in the stage of implementing into the company. The third part includes questions regarding the drivers, barriers, activities and benefits of implementing GSCM. Other parts of the survey represent activities within GSCM. Total survey consists of 57 questions. In this paper, only the results of the third part of the survey (questions regarding the drivers, barriers, activities and benefits of implementing GSCM) will be analyzed.

\section{RESULTS OF THE SURVEY}

The invitation for the survey was sent to 3,257 big, medium and small companies of different business categories. The survey was carried out in three independent parts. The results are shown for the third part of the survey. 69 complete answers for the second part of the survey were received. The survey results [7] are presented for the Croatian companies in following parts:

- Current state of GSCM,

- Drivers for implementation of GSCM,

- Barriers for implementation of GSCM.

\subsection{Current State of GSCM}

As mentioned above, there are eight models within the GSCM concept. Fig. 7 shows the level of familiarity with the GSCM models, while Fig. 8 shows the level of implementation of the GSCM models within a company.

By analyzing Figs. 7 and 8, it cannot be immediately said whether there is any difference between the level of familiarity and the level of implementing the GSCM models. Because of that $\chi^{2}$ test was conducted to determine the statistical significance of the differences. The result of $\chi^{2}$ test for the level of familiarity with models is interesting. There are two possible conclusions here, depending on the amount of error we want to have. Thus, with the $5 \%$ probability for an error, it can be concluded that there is a difference between the levels of familiarity with the GSCM models within a company. Also, with $10 \%$ probability of an error, it can be concluded that there is no difference between the familiarity levels of the GSCM models within a company. The $\chi^{2}$ test conducted for the level of implementation of the GSCM models within a company confirms that with $5 \%$ probability of error there is no difference between them.

As mentioned before, there are eight models within the GSCM concept. The idea is to rank them according to the relevance and to see which of them are most relevant for Croatian companies. This has been done by Friedman's test that converts scores to rankings, whereby results with the same rank get the so-called bound or common rank. This test is used when there are a number of repeated experimental situations or repeated measurements. Although the test primarily serves to verify the hypothesis, here it will be used to rank the data according to the relevance.

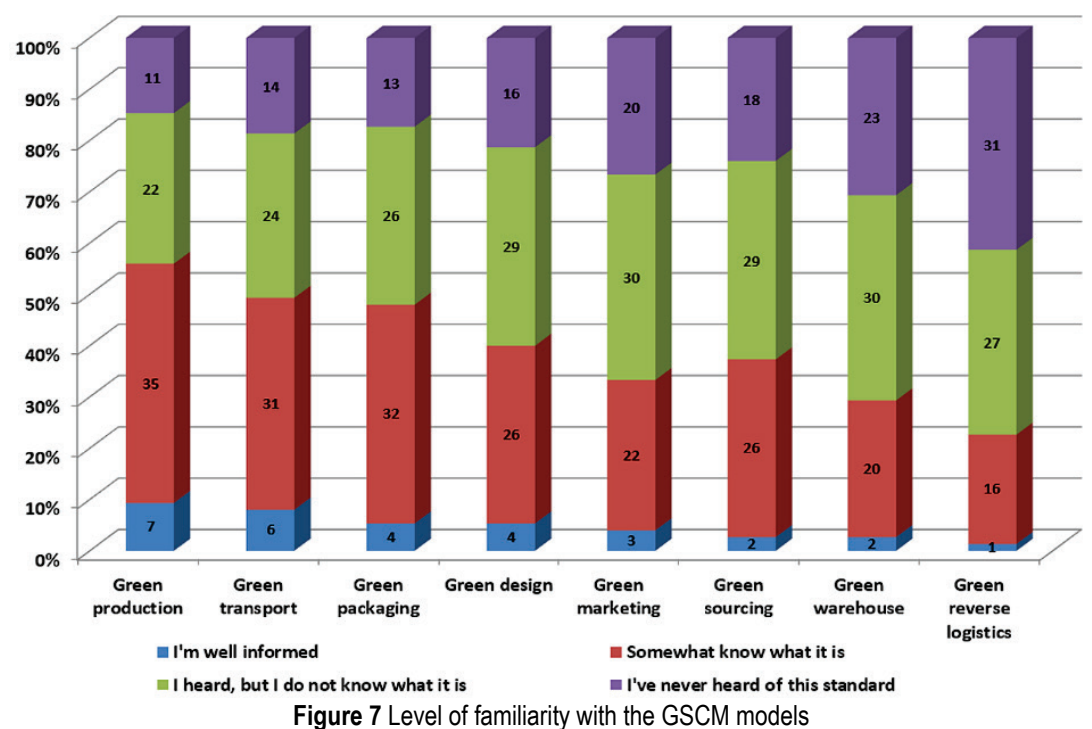

Figure 7 Level of familiarity with the GSCM models 


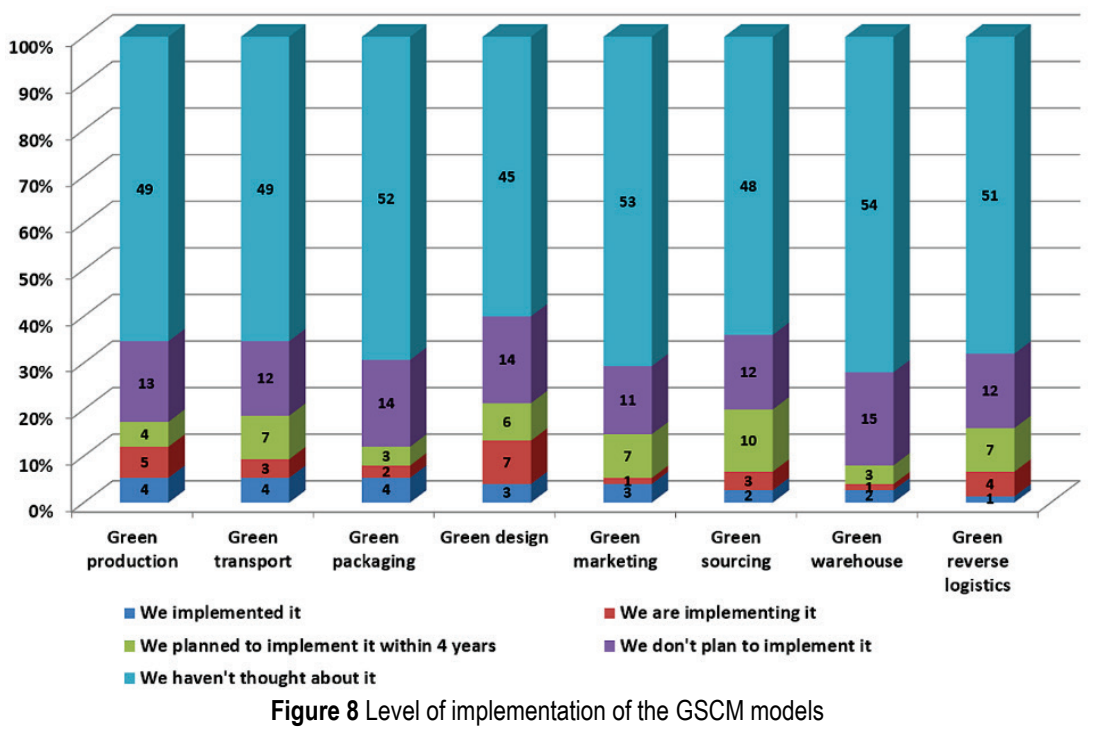

Table 1 The most significant models of GSCM

\begin{tabular}{lccc}
\hline $\begin{array}{c}\text { Model within the GSCM } \\
\text { concept }\end{array}$ & $\begin{array}{c}\text { Average } \\
\text { rank }\end{array}$ & $\begin{array}{c}\text { Arithmetic } \\
\text { mean }\end{array}$ & $\begin{array}{c}\text { Standard } \\
\text { deviation }\end{array}$ \\
\hline Green production & 6.09 & 6.09 & 2.27 \\
\hline Green sourcing & 5.35 & 5.35 & 2.39 \\
\hline Green transport & 4.79 & 4.79 & 1.83 \\
\hline Green packaging & 4.57 & 4.57 & 1.83 \\
\hline Green design & 4.23 & 4.23 & 2.24 \\
\hline Green warehouse & 4.09 & 4.09 & 1.97 \\
\hline Green marketing & 4.00 & 4.00 & 2.49 \\
\hline Green reverse logistics & 2.88 & 2.88 & 1.84 \\
\hline
\end{tabular}

Tab. 1 shows the most significant GSCM models in Croatian companies. From Tab. 1, it is apparent that the companies consider green production and green sourcing as the models of GSCM which are of greatest significance for the process of implementation. On the other hand, green marketing and green reverse logistics are the models of GSCM that have the lowest impact on the process of implementation. These results can be used to help companies decide which model of GSCM is better to use or implement in their company.

\subsection{Drivers for the Implementation of GSCM}

Based on literature review, Holt's doctoral thesis [10], GSCM drivers can be divided into eight categories:

- Legislative regulations imply the need of companies to comply with the Croatian environmental regulations, the EU's environmental regulations and the forthcoming regulations. It should be noted that the above mentioned EU directives and EPAs already define how companies must adapt to them. In the opinion of the authors of this paper and in the opinion of Holt [9], this is one of the most important factors for the implementation of GSCM.

- Social pressure is a term which defines the pressure of society on how the enterprise or organization should behave. Many companies have to comply with safety and health standards (OHSAS18001, ISO14001) to be able to deal with specific supply chain participants. Likewise, it is very important for marketing to maintain a certain image of an environmentally conscious company or organization, so they do not lose existing customers, as well as to gain future customers or users.

- Professional and industrial associations (bodies) represent the pressure of trade unions, trade associations and others to implement GSCM within the company.

- Financial factors also greatly encourage the implementation of GSCM into companies. Many companies have achieved significant savings by implementation of some elements of GSCM into the enterprise. Toyota has saved $\$ 3.6$ million in 1990 by developing standard packaging for suppliers to reuse or recycle the packaging [10]. Public Service Electric and Gas Company has saved more than $\$ 2$ million by reducing the number of suppliers from 270 to 9 [2]. From financial factors, the biggest emphasis is on reducing operating costs within a company.

- Supply chain factors imply pressure and initiatives by upstream and downstream supply chains.

- Internal factors are drivers that occur within the company itself. They can come from a director or an employee and can also be part of an organization's corporate culture. This is primarily the case if business operates in an environment where employees live, and thus want to improve the quality of their lives.

- Competitiveness factors are largely linked to financial factors. These factors want to create new profits on the market and to achieve results better than competitors or at least keep up with the competition.

- Risk factors imply drivers that reduce the risk of potential pollution related to company products or services and disposal of products at the end of their life cycle.

When the GSCM drivers are analyzed, as shown in Tab. 2 , it can be seen that within seven most significant drivers, the most significant factors are the competitive factors. This implies that there is a desire to compete better, keep up with competition, and to create new profits. Adapting businesses 
to the existing EU environmental regulations and upcoming environmental regulations is a legislative regulation that is within the seven most significant drivers.

By analyzing seven least significant drivers, we can see that social factors are prevailing (to maintain or present an image of an environmentally or socially responsible company/internationally societal public expectation/societal public expectation in Croatia). Employee pressure (internal factor) and union pressure (professional and industrial associations/bodies) are the drivers with the least impact on the introduction of GSCM. From the above-mentioned, it can be concluded that social factors and pressure (from employees, trade unions, shareholders, etc.) are drivers with the least impact on the introduction of GSCM into the enterprise.

Table 2 Rank of the drivers in the implementation of GSCM

\begin{tabular}{|c|c|c|c|c|}
\hline \multicolumn{2}{|c|}{ Drivers in the implementation of GSCM } & Average rank & Arithmetic mean & $\begin{array}{r}\text { Standard } \\
\text { deviation }\end{array}$ \\
\hline Competitiveness factors & In order to perform better than our competitors & 15.75 & 4.12 & 1.38 \\
\hline Competitiveness factors & In order to keep up with competitors & 15.66 & 4.17 & 1.23 \\
\hline Legislative regulations & $\begin{array}{l}\text { To comply with current EU environmental } \\
\text { legislation }\end{array}$ & 15.36 & 4.05 & 1.42 \\
\hline Internal factors & $\begin{array}{l}\text { The CEO is committed to environmental } \\
\text { improvement }\end{array}$ & 14.81 & 4.07 & 1.29 \\
\hline Competitiveness factors & New profit opportunities in the market & 14.59 & 3.96 & 1.37 \\
\hline Legislative regulations & $\begin{array}{l}\text { In order to pre-empt possible legislation in the } \\
\text { future }\end{array}$ & 14.44 & 3.89 & 1.47 \\
\hline Financial factors & To achieve savings in operating costs & 14.25 & 3.96 & 1.38 \\
\hline Risk & $\begin{array}{l}\text { In order to reduce health and safety risks } \\
\text { associated with our goods, services and } \\
\text { operational practices }\end{array}$ & 14.21 & 3.96 & 1.32 \\
\hline Legislative regulations & $\begin{array}{l}\text { To comply with current Croatian government } \\
\text { environmental regulations }\end{array}$ & 13.87 & 3.87 & 1.38 \\
\hline Internal factors & $\begin{array}{l}\text { Environmental responsibility is part of the } \\
\text { organizational culture of our company }\end{array}$ & 13.57 & 3.89 & 1.29 \\
\hline Risk & $\begin{array}{l}\text { In order to reduce health and safety risks } \\
\text { associated with the disposal of our products or } \\
\text { materials we use at the end of their life cycle }\end{array}$ & 13.37 & 3.87 & 1.33 \\
\hline Supply chain factors & $\begin{array}{l}\text { Pressure or encouragement from businesses you } \\
\text { supply with goods and services }\end{array}$ & 12.60 & 3.72 & 1.36 \\
\hline $\begin{array}{l}\text { Professional and industrial } \\
\text { associations (bodies) }\end{array}$ & $\begin{array}{l}\text { Pressure from professional bodies, trade } \\
\text { associations }\end{array}$ & 11.85 & 3.65 & 1.29 \\
\hline Social pressure & Pressure from green action groups (Greenpeace) & 11.51 & 3.56 & 1.35 \\
\hline Social pressure & Public opinion in local area & 11.36 & 3.55 & 1.37 \\
\hline Risk & $\begin{array}{l}\text { In order to reduce the public's perceived risk } \\
\text { associated with our company }\end{array}$ & 11.35 & 3.57 & 1.31 \\
\hline Supply chain factors & Pressure from individual consumers & 11.30 & 3.61 & 1.22 \\
\hline Social pressure & $\begin{array}{l}\text { To maintain or present an image of an } \\
\text { environmentally or socially responsible } \\
\text { company }\end{array}$ & 11.26 & 3.51 & 1.40 \\
\hline Financial factors & Pressure from shareholders and investors & 11.10 & 3.41 & 1.47 \\
\hline Social pressure & Internationally societal public expectation & 11.07 & 3.49 & 1.35 \\
\hline Financial factors & Pressure from insurance industry & 10.54 & 3.37 & 1.41 \\
\hline Social pressure & Societal public expectation in Croatia & 10.47 & 3.43 & 1.29 \\
\hline Internal factors & Pressure from employees & 8.09 & 3.15 & 1.16 \\
\hline $\begin{array}{l}\text { Professional and industrial } \\
\text { associations (bodies) }\end{array}$ & Pressure from the trade union & 7.61 & 2.99 & 1.22 \\
\hline
\end{tabular}

Tab. 3 shows the factor analysis of the drivers in the implementation of GSCM. The factor analysis was performed in order to group and explain numerous drivers of the GSCM implementation by minimal number of factors. The criterion for acceptance of the factor is when factor loading has a value of more than 0.70 .

From the Tab. 2, we can see that factor 1 describes all internal GSCM drivers, thus this factor can be called the internal factor of the GSCM implementation. In addition to internal drivers, factor 1 also describes other risk based drivers, but these drivers can easily be classified as internal, since they are closely related to the organization of the company. A driver "to maintain or present an image of an environmentally or socially responsible company" is equally described by factor 1 and factor 2 and will be placed under factor 2 .

Factor 2 describes the drivers that are linked to legislative regulations and social pressure. As such, it can be called the factor of legal regulation and social pressure. 
Factor 3 can be defined as a financial factor as it describes two financial drivers, one risk related driver and one driver related to professional and industrial associations (bodies). This is especially true when one takes into account that the pressure of the trade union may be placed under financial drivers because it affects the company's finances.

\begin{tabular}{|c|c|c|c|c|c|}
\hline & Drivers in the implementation of GSCM & Factor 1 & Factor 2 & Factor 3 & Factor 4 \\
\hline \multirow{3}{*}{ Legislative regulations } & $\begin{array}{l}\text { To comply with current Croatian government environmental } \\
\text { regulations }\end{array}$ & 0.1682 & 0.7544 & -0.0132 & 0.3394 \\
\hline & To comply with current EU environmental legislation & 0.1810 & 0.7439 & 0.0675 & 0.4348 \\
\hline & In order to pre-empt possible legislation in the future & 0.1728 & 0.6981 & 0.0195 & 0.3109 \\
\hline \multirow{5}{*}{ Social pressure } & Public opinion in local area & 0.2427 & 0.7835 & 0.2950 & 0.1546 \\
\hline & Societal public expectation in Croatia & 0.2603 & 0.7787 & 0.2916 & 0.2054 \\
\hline & Internationally societal public expectation & 0.4413 & 0.7201 & 0.2590 & -0.0888 \\
\hline & Pressure from green action groups (Greenpeace) & 0.1846 & 0.6519 & 0.2324 & 0.0866 \\
\hline & $\begin{array}{l}\text { To maintain or present an image of an environmentally or } \\
\text { socially responsible company }\end{array}$ & 0.4422 & 0.4370 & 0.1975 & 0.3953 \\
\hline \multirow{2}{*}{$\begin{array}{l}\text { Professional and industrial } \\
\text { associations (bodies) }\end{array}$} & Pressure from professional bodies, trade associations & 0.2943 & 0.3849 & 0.3715 & 0.5834 \\
\hline & Pressure from the trade union & 0.1481 & 0.4274 & 0.6545 & 0.2742 \\
\hline \multirow{3}{*}{ Financial factors } & Pressure from shareholders and investors & 0.2842 & 0.1144 & 0.7978 & 0.2411 \\
\hline & Pressure from insurance industry & 0.2404 & 0.1478 & 0.8425 & 0.2138 \\
\hline & To achieve savings in operating costs & 0.5475 & 0.1301 & 0.2241 & 0.6121 \\
\hline \multirow[t]{2}{*}{ Supply chain factors } & $\begin{array}{l}\text { Pressure or encouragement from businesses you supply with } \\
\text { goods and services }\end{array}$ & 0.3787 & 0.0867 & 0.4966 & 0.5622 \\
\hline & Pressure from individual consumers & 0.5330 & 0.2364 & 0.3950 & 0.5037 \\
\hline \multirow{3}{*}{ Internal factors } & Pressure from employees & 0.5967 & 0.3641 & 0.2278 & 0.2434 \\
\hline & The CEO is committed to environmental improvement & 0.7259 & 0.2423 & 0.2863 & 0.1994 \\
\hline & $\begin{array}{l}\text { Environmental responsibility is part of the organizational culture } \\
\text { of our company }\end{array}$ & 0.7105 & 0.3715 & 0.3066 & 0.2578 \\
\hline \multirow{3}{*}{ Competitiveness factors } & New profit opportunities in the market & 0.1856 & 0.4214 & 0.2360 & 0.7690 \\
\hline & In order to keep up with competitors & 0.3649 & 0.1878 & 0.4101 & 0.6748 \\
\hline & In order to perform better than our competitors & 0.4832 & 0.2069 & 0.2780 & 0.6710 \\
\hline \multirow{3}{*}{ Risk } & $\begin{array}{l}\text { In order to reduce health and safety risks associated with our } \\
\text { goods, services and operational practices }\end{array}$ & 0.7852 & 0.2730 & 0.1496 & 0.2992 \\
\hline & $\begin{array}{l}\text { In order to reduce health and safety risks associated with the } \\
\text { disposal of our products or materials we use at the end of their } \\
\text { life cycle }\end{array}$ & 0.7671 & 0.2201 & 0.2813 & 0.3189 \\
\hline & $\begin{array}{l}\text { In order to reduce the public's perceived risk associated with our } \\
\text { company }\end{array}$ & 0.4065 & 0.2950 & 0.5699 & 0.3642 \\
\hline
\end{tabular}

Finally, factor 4 can be called competitiveness factor because it describes all of them. In addition to the competitiveness drivers, it describes the driver "to achieve savings in operating costs", which, of course, leads to an increase in company competencies. Factor 4 also describes two drivers associated with the pressure of professional and trade associations (bodies), and the one driver associated with the pressure or initiatives from the companies that are supplying goods or services.

Although some of the drivers in the mentioned category do not belong under the same factors, such category will not make significant mistakes and it can freely be said that these four factors can replace the above mentioned eight categories of the GSCM implementation drivers. Factor 2 describes two categories, so it will be divided into two categories. In accordance with the above-mentioned, Tab. 4 shows a new actuator category according to the factor analysis results, by which the number of categories decreases from eight to five.

\subsection{Barriers for the Implementation of GSCM}

Based on the literature review, Holt [10], Ageron et al. [13], and Khiewnavawong [14], the barriers to GSCM implementation are divided into six categories:

- Supply Chain participants (suppliers and customers) category includes barriers related to the upstream and downstream part of the supply chain, i.e. buyers and suppliers.

- Economic factors related to the investments in "green" projects and prices of "green" products.

- Perception implies the perception of environmental thinking within a company. Often, employees have a negative attitude towards environmental initiatives, which at the start can condemn projects and bring downfall.

- Motivation is a very important category when implementing GSCM into a company because it is very important in some phases to motivate employees. This includes barriers whose existence affects employee motivation and their desire, or resistance to change. 
- Implementation implies barriers that may make it difficult to implement GSCM within the company. These can be legislative regulations that change, the change of technology, etc.
- Resource limitation includes constraints that can be associated with human resource constraints, government support, and the lack of material resources (raw materials, technology and equipment).

Table 4 The new classification of the drivers in the implementation of GSCM

\begin{tabular}{ll} 
Legislative regulations & To comply with current Croatian government environ \\
\cline { 2 - 2 } & To comply with current EU environmental legislation \\
\hline In order to pre-empt possible legislation in the future
\end{tabular}

Public opinion in local area

Societal public expectation in Croatia

Social pressure

Internationally societal public expectation

Pressure from green action groups (Greenpeace)

To maintain or present an image of an environmentally or socially responsible company

Pressure from individual consumers

Pressure from employees

Internal factors

The CEO is committed to environmental improvement

Environmental responsibility is part of the organizational culture of our company

In order to reduce health and safety risks associated with our goods, services and operational practices

In order to reduce health and safety risks associated with the disposal of our products or materials we use at

the end of their life cycle

Pressure from the trade union

Financial factors $\quad$ Pressure from shareholders and investors

Pressure from insurance industry

In order to reduce the public's perceived risk associated with our company

Pressure from professional bodies, trade associations

To achieve savings in operating costs

Competitiveness factors

Pressure or encouragement from businesses you supply with goods and services

New profit opportunities in the market

In order to keep up with competitors

In order to perform better than our competitors

Tab. 5 shows the rank of barriers in the implementation of GSCM in Croatian companies. From Tab. 5 we can see that among seven barriers with the strongest influence on the GSCM implementation, four of them are connected with the economics factors. Those factors are related to green initiatives and products (high operating cost, high investment cost, higher cost of raw material, higher cost of products). Other three are connected with supply chain participants, but are also related to the costs regarding the participants of the supply chain. The last barrier among the seven with most influence is the one connected with the implementation that the laws/regulations keep changing and it is hard to find the right information.

On the other hand, seven barriers with the lowest influence on the implementation of GCSM are connected with the implementation that it is hard to follow technology which is changing all the time and with the problem of measuring the results of green project. Here are also barriers related to the resources limitation (poor quality of environmentally friendly resources), supply chain participants (size of the company), perception (company believes that green initiatives are not widely accepted or used in an industrial sector or geographic area) and motivation (that there are some powerful individuals in the company that resist the change).

Factor analysis was also conducted for the barriers for GSCM implementation, but the results could not be interpreted due to low degree of parsimony. Hence, the barriers should be interpreted individually.

Table 5 Rank of the barriers in the implementation of GSCM

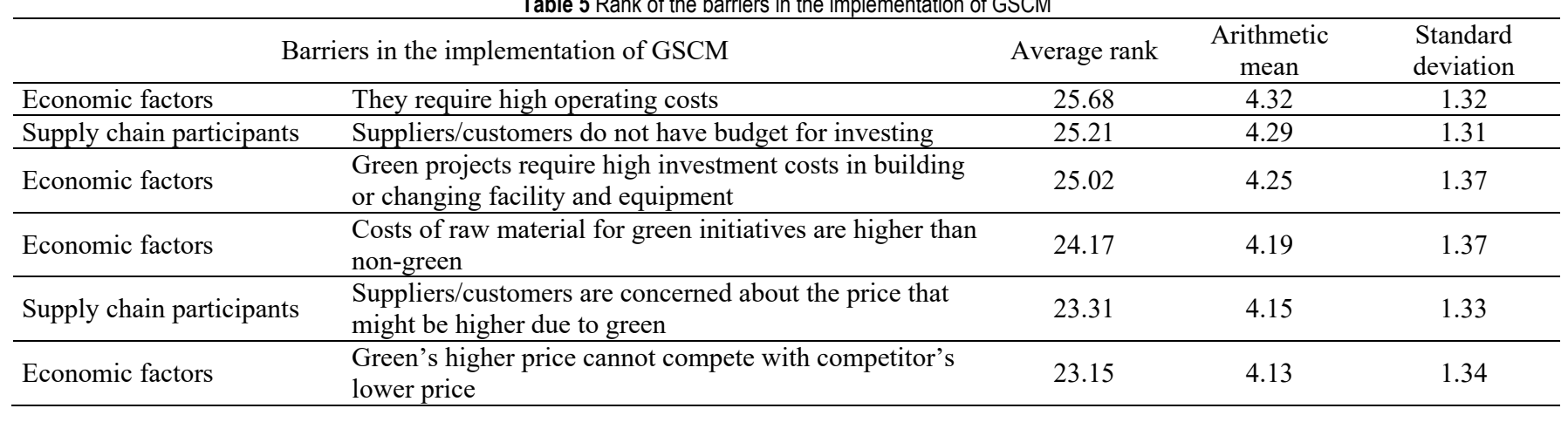


Table 5 Rank of the barriers in the implementation of GSCM (continuation)

\begin{tabular}{|c|c|c|c|c|}
\hline \multicolumn{2}{|c|}{ Barriers in the implementation of GSCM } & Average rank & $\begin{array}{c}\text { Arithmetic } \\
\text { mean }\end{array}$ & $\begin{array}{l}\text { Standard } \\
\text { deviation }\end{array}$ \\
\hline Implementation & $\begin{array}{l}\text { The laws/regulations keep changing and it is hard to find } \\
\text { the right information }\end{array}$ & 22.24 & 4.12 & 1.28 \\
\hline Supply chain participants & $\begin{array}{l}\text { Suppliers/customers do not have information, resources } \\
\text { and expertise to implement }\end{array}$ & 22.17 & 3.99 & 1.44 \\
\hline Economic factors & $\begin{array}{l}\text { Fear that the benefits of implementing environmental } \\
\text { thinking will not return their investment }\end{array}$ & 21.66 & 3.91 & 1.42 \\
\hline Resources limitation & Lack of support from government & 21.23 & 3.97 & 1.41 \\
\hline Resources limitation & Limitation of technical knowledge & 20.67 & 3.87 & 1.39 \\
\hline Resources limitation & Lack of process standardization & 20.27 & 3.89 & 1.36 \\
\hline Resources limitation & Lack of knowledge to implement green & 20.19 & 3.83 & 1.39 \\
\hline Resources limitation & Lack of human resources that specialize in green & 20.17 & 3.79 & 1.45 \\
\hline Motivation & $\begin{array}{l}\text { The company regards new investment in redesigning the } \\
\text { product to be green as fruitless }\end{array}$ & 19.98 & 3.77 & 1.45 \\
\hline Supply chain participants & Size and complexity of the supply chain & 19.55 & 3.69 & 1.49 \\
\hline Perception & Top management does not believe in green & 19.51 & 3.56 & 1.60 \\
\hline Perception & $\begin{array}{l}\text { The company believes that green is complicated and } \\
\text { unattainable }\end{array}$ & 19.09 & 3.69 & 1.43 \\
\hline Implementation & $\begin{array}{l}\text { The company does not comply with regulations or } \\
\text { permits }\end{array}$ & 19.01 & 3.69 & 1.49 \\
\hline Supply chain participants & $\begin{array}{l}\text { Lack of environmental standards and audit programs at } \\
\text { the suppliers/customers }\end{array}$ & 19.01 & 3.61 & 1.53 \\
\hline Perception & $\begin{array}{l}\text { The company does not feel responsible for the } \\
\text { environmental issues }\end{array}$ & 18.67 & 3.63 & 1.44 \\
\hline Supply chain participants & $\begin{array}{l}\text { Suppliers/customers do want to cooperate in green with } \\
\text { us }\end{array}$ & 18.65 & 3.67 & 1.43 \\
\hline Perception & $\begin{array}{l}\text { The company is uncertain about the environmental } \\
\text { benefits of the green initiatives }\end{array}$ & 18.53 & 3.60 & 1.50 \\
\hline Supply chain participants & Human skills of the suppliers/customers & 18.04 & 3.67 & 1.36 \\
\hline Perception & $\begin{array}{l}\text { The company believes that green is not important or } \\
\text { relevant to the business }\end{array}$ & 18.00 & 3.61 & 1.42 \\
\hline Economic factors & $\begin{array}{l}\text { There is not enough market-based incentives to invest in } \\
\text { green }\end{array}$ & 17.95 & 3.64 & 1.32 \\
\hline Motivation & Focal company on previous experiences on sustainability & 17.85 & 3.63 & 1.41 \\
\hline Resources limitation & Lack of environmentally friendly resources & 17.81 & 3.67 & 1.41 \\
\hline Motivation & Lack of support and commitment from top management & 17.56 & 3.45 & 1.48 \\
\hline Implementation & Lack of communication among the departments involved & 17.33 & 3.51 & 1.46 \\
\hline Supply chain participants & $\begin{array}{l}\text { Suppliers/customers are hesitant in the performance on } \\
\text { green products/process }\end{array}$ & 17.32 & 3.51 & 1.42 \\
\hline Motivation & $\begin{array}{l}\text { Green is not a challenging technological innovation } \\
\text { opportunity for our company }\end{array}$ & 16.79 & 3.51 & 1.36 \\
\hline Motivation & $\begin{array}{l}\text { There are some powerful individuals in the company that } \\
\text { resist change }\end{array}$ & 16.73 & 3.35 & 1.58 \\
\hline Perception & $\begin{array}{l}\text { The company believes that green initiatives are not } \\
\text { widely accepted or used in an industrial sector or } \\
\text { geographic area }\end{array}$ & 16.40 & 3.45 & 1.40 \\
\hline Supply chain participants & Suppliers/customers company size & 16.26 & 3.47 & 1.40 \\
\hline Implementation & $\begin{array}{l}\text { It is hard to follow current technology because it changes } \\
\text { all the time }\end{array}$ & 15.89 & 3.52 & 1.33 \\
\hline Resources limitation & Poor quality of environmentally friendly resources & 15.29 & 3.36 & 1.44 \\
\hline Implementation & It is hard to measure/assess results of green projects & 14.66 & 3.31 & 1.38 \\
\hline
\end{tabular}

\section{CONCLUSION}

As mentioned earlier in the paper, some of the questions are taken from already conducted surveys in the EU and the USA. Drivers of implementation of GSCM can be compared with the survey conducted by Holt in the British companies [10]. It can be concluded that there are certain similarities and differences between the drivers in the UK and Croatia. In both countries, among the most significant drivers are the drivers associated with legislative regulations category. The difference is in the fact that companies in the UK are considering the risk factor more, while Croatian companies are considering competitiveness factors more. Also, among the most significant drivers in both cases there is an internal 
factor: in the British companies that is "environmental responsibility is part of the organizational culture of our company", and in Croatian companies that is "the CEO is committed to environmental improvement".

As a conclusion it can be said that companies in the UK look at GSCM as a concept that, apart from compliance with legislative regulations, can reduce the impact and risk to the environment and health of employees. On the other hand, Croatian companies also look at GSCM as a concept that allows easier compliance with legislative regulations, but it also helps to create new profits and keep pace or even be better than competition. Generally speaking, companies in the UK, when it comes to GSCM drivers, have a better developed ecological awareness.

When we look at least significant drivers, there is also a certain similarity between the results of these two surveys. In the UK and Croatia, amongst the least significant drivers are as follows: "pressure from employees" (as an internal factor), "pressure from shareholders and investors", and "pressure from insurance industry" (as a financial factor). The difference is that supply chain factors prevail in the UK, while social pressures prevail in Croatia. Furthermore, it can be concluded that neither in the UK nor in Croatia the pressure within the supply chain and social pressure does not contribute to the implementation of GSCM into the enterprise.

Research questions for the barriers in the implementation of GSCM were taken from three different surveys: Ageron et al. [13] conducted in France, Holt [10] research conducted in the UK, Khiewnavawong [14] research conducted in the electrical and electronic industry in the USA. Because of that, the data cannot be compared unequivocally, but will be compared shortly. When looking at the results of the most significant barriers in Croatia (Tab. 5), it can be seen that four of seven most significant barriers belong into the economic factors category. There are two barriers associated with the supply chain factors, but are also related to the price. The last barrier is related to the implementation of GSCM. In the surveys conducted in other countries [10, 13, 14], most significant barriers are the ones connected with the economic factors such as the higher price of green products, greater cost of the raw materials, lack of human resources, higher operating costs, and more. Therefore, it can be concluded that there is no significant difference in the results between the compared surveys.

On the other hand, when looking at the least significant barriers, the same conclusion is reached. Although certain barriers do not coincide, barriers with the least impact are those that are related to the motivation, perception and implementation of GSCM in the enterprise. Most often, however, there are barriers related to the size of the company, difficulties in following new technology, and measuring the results of green projects. Generally, regarding the barriers, there are not so many differences in answers comparing Croatian companies and companies from other countries.

Results of this paper can help companies in implementing GSCM into their organizations so as to guide them through the process of implementation according to the most and less significant drivers and barriers. This is especially important if we take into consideration that the companies are not familiar with the GSCM concept and its models.

\section{REFERENCES}

[1] Psomopoulos, C. S., Skoula, I., Karras C., Chatzimpiros, A., \& Chionidis, M. (2010). Electricity savings and CO2 emissions reduction in buildings sector: How important the network losses are in the calculation? Energy, 35(1), 485-490. https://doi.org/10.1016/j.energy.2009.10.016

[2] Houghton, J. T., Jenkins, G. J., \& Ephraums, J. J. (1990). Climate change, the IPCC scientific assessment, Cambridge: Cambridge University Press.

[3] Liu, C. C. (2007). An extended method for key factors in reducing $\mathrm{CO}_{2}$ emissions. Applied Mathematics and Computation, 189(1), 440-451. https://doi.org/10.1016/j.amc.2006.09.141

[4] United Nations, from https://unfccc.int/2860.php (accessed 19.03.2014).

[5] Srivastara S. K. (2007). Green Supply-Chain Management: A State-of-The-Art Literature Review. International Journal of Management Reviews, 9(1), 53-80.

[6] Bacallan, J. J. (2000). Greening the supply chains. Business and Environment, 6(5), 11-12.

[7] Opetuk, T. (2016). Model of Green supply chain management implementation, Doctoral Thesis, University of Zagreb, Faculty of mechanical engineering and naval architecture.

[8] Council of Supply Chain Management Professionals, from https://cscmp.org/ (accessed on 24.04.2012).

[9] Đukić, G., Česnik, V., \& Opetuk, T. (2010). Order-picking Methods and Technologies for Greener Warehousing, Strojarstvo-Journal for Theory and Application in Mechanical Engineering, 52, 23-32.

[10] Holt, D. L. (2005). The Development and Empirical Testing of a Pressure/Response Model of Green Supply Chain Management amongst a cross-sectoral sample of members of The Chartered Institute of Purchasing and Supply, Doctoral Theses, Middlesex University, London.

[11] Chen, C. C., Shih, H. S., Shjur, H. J., \& Wuc, K. S. (2012). A business strategy selection of green supply chain management via an analytic network process, Computers and Mathematics with Applications, 64 (8), 2544-2557. https://doi.org/10.1016/j.camwa.2012.06.013

[12] Kuo-Chung, S., Chin-Shan, L., \& Shaorui, L. (2010). A taxonomy of green supply chain management capability among electronics-related manufacturing firms in Taiwan. Journal of Environmental Management, 91(5), 1218-1226. https://doi.org/10.1016/j.jenvman.2010.01.016

[13] Ageron, B., Gunasekaran, A., \& Spalanzani, A. (2012). Sustainable supply management: An empirical study. International Journal of Production Economics, 140(1), 168182. https://doi.org/10.1016/j.jpe.2011.04.007

[14] Khiewnavawongsa, S. (2011). Barriers to green supply chain implementation in the electronics industry, Doctoral Theses, Purdue University, Indiana. 
Authors' contacts:

Tihomir OPETUK, PhD

University of Zagreb,

Faculty of Mechanical Engineering and Naval Architecture,

Department of Industrial Engineering, Chair of Production Design,

Ivana Lučića 1, 10000 Zagreb, Croatia

Tel. +3851/6168332

E-mail: thomir.opetuk@fsb.hr

Goran DUKIC, PhD, Full Professor

University of Zagreb,

Faculty of Mechanical Engineering and Naval Architecture,

Department of Industrial Engineering, Chair of Production Design,

Ivana Lučića 1, 10000 Zagreb, Croatia

Tel. +385 1/61 68381

E-mail: goran.dukic@fsb.hr

Hrvoje CAJNER, PhD, Assistant Professor

University of Zagreb,

Faculty of Mechanical Engineering and Naval Architecture,

Department of Industrial Engineering, Chair of Production Control,

Ivana Lučića 1, 10000 Zagreb, Croatia

Tel. +385 1/6168331

E-mail: hrvoje.cajner@fsb.hr

Davor KOLAR, mag. ing. mech.

University of Zagreb,

Faculty of Mechanical Engineering and Naval Architecture,

Department of Industrial Engineering, Chair of Production Control,

Ivana Lučića 1, 10000 Zagreb, Croatia

Tel. +385 1/6168355

E-mail: davor.kolar@fsb.hr 